Available online at http://jurnal.stmikroyal.ac.id/index.php/jurteksi

\title{
PENERAPAN WATERFALL DALAM MEMBANGUN SISTEM INFORMASI PENGOLAHAN DATA PELAKSANAAN KONSTRUKSI PEMBANGUNAN JALAN
}

\author{
Rizaldi \\ Program Studi Sistem Informasi, STMIK Royal \\ email: rizaldipiliang.rp@gmail.com
}

\begin{abstract}
PT. Barettamuda Pratama Padang runs on the distribution of road construction materials at PU Bina Marga. Applications used for data processing of construction materials is limited to Microsoft Office. Problems that occur on the system that is running, difficulty when looking for the required data, often occur repetition of data when writing data on lapora, error writing data so that the reported data does not match the actual data. With the ongoing system, resulting in ineffectiveness in working on reports and time to process data on the construction of road construction is inefficient. In the proposed system is a computerized system to help process the data construction of road construction so that the problems encountered so far can be resolved. The construction of the old system on the new system will apply the Waterfall method. Excess waterfall method, practical in their systems, Development of a structured and controlled make the quality of the software is maintained.
\end{abstract}

Keywords: information system, construction of Road construction, waterfall method

\begin{abstract}
Abstrak: PT. Barettamuda Pratama Padang berjalan pada kegiatan pendistribusian bahan pembangunan jalan pada PU Bina Marga. Aplikasi yang digunakan untuk pengolahan data bahan konstruksi hanya sebatas Microsoft Office. Permasalahan yang terjadi pada sistem yang sedang berjalan, kesulitan ketika mencari data yang dibutuhkan, sering terjadi pengulangan data saat menuliskan data tersebut pada lapora, kesalahan penulisan data sehingga data yang dilaporkan tidak sesuai dengan data yang sebenarnya. Dengan sistem yang sedang berjalan,mengakibatkan ketidakefektifan dalam mengerjakan laporan dan waktu untuk mengolah data pelaksanaan konstruksi pembanguan jalan tidak efesien. Pada sistem yang diusulkan merupakan sistem yang sudah terkomputerisasi untuk membantu memproses data pelaksanaan konstruksi pembangunan jalan sehingga permasalahan yang dihdapi selama ini dapat teratasi. Pembangunan sistem lama pada sistem baru akan menerapkan metode Waterfall. Kelebihan metode waterfall, praktis dalam merekaya sistem, Pengembangan yang terstruktur dan terkontrol membuat kualitas software tetap terjaga.
\end{abstract}

Kata kunci: sistem informasi, konstruksi pembangunan jalan, metode waterfall 
Available online at http://jurnal.stmikroyal.ac.id/index.php/jurteksi

\section{PENDAHULUAN}

PT. Barettamuda Pratama Padang berjalan pada kegiatan pelaksanaan konstruksi pembangunan jalan, baik itu jalan raya, jembatan, terowongan, sampai pengalihan tumbuh-tumbuhan. Berkaitan dengan aplikasi yang digunakan dalam mengolah data pelaksanaan konstruksi pembangunan jalan, PT. Barettamuda Pratama Padang belum menggunakan sistem informasi dalam mengolah data pelaksanaan konstruksi jalan tersebut. Aplikasi yang digunakan hanya sebatas Microsoft Office. Sebagai contoh, untuk membuatkan surat dan proposal perusahaan ini menggunakan Microsoft Word, dan beberapa laporan penting harian dan bulanan menggunakan Microsoft Excel.

Dari aplikasi yang digunakan saat ini ada beberapa keluhan yang dirasakan oleh pihak manajemen, yaitu laporan sering terlambat disebabkan pengolahan data dan pembuatan laporan dikerjakan pada Microsoft Excel, Kesalahan dalam pembuatan laporan sering terjadi sehingga informasi yang disajikan tidak valid. Selain itu, terjadi kesulitan ketika mencari data yang dibutuhkan, selama ini staf administrasi membolak-balikkan lembaran kertas yang menumpuk atau sheet pada Microsoft Excel untuk menemukan data yang dicari. Selain itu, terjadi pengulangan data saat menuliskan data tersebut pada laporan yang berbeda, pekerjaan seperti ini menyita waktu dalam mengolah data. Penulisan, pengkoreksian, dan pencarian data merupakan pekerjaan yang dilakukan oleh staf administrasi setiap hari. Kelemahan yang terjadi pada sistem yang digunakan mengakibatkan ketidakefektifan dalam mengerjakan laporan dan waktu yang digunakan tidak efesien.

Dari permasalahan yang terjadi saat ini, peneliti dapat memberikan solusi dengan cara membangun sistem informasi pengolahan data pelaksanaan konstruksi pembangunan jalan. Adapun acuan pengembangan sistem merujuk kepada metode waterfall. Kelebihan metode waterfall, praktis dalam merekaya sistem, pengembangan yang terstruktur dan terkontrol membuat kualitas software tetap terjaga. Disisi lain model ini merupakan jenis model yang bersifat dokumen lengkap, sehingga proses pemeliharaan dapatdilakukan dengan mudah. Dengan keistimewaan yang dimiliki metode waterfall ini, banyak peneliti menjadikan metode ini sebagai dasar untuk mengembangan sistem, salah satunya adalah (Angga, 2015) dengan judul penelitian "Pengembangan Aplikasi Penjualan dan Pembelian Bahan Bangunan di Toko Bagja Jaya Menggunakan Metodologi Waterfall”.

\section{Sistem Informasi}

Menurut Tata Sutabri (2012:46) menjelaskan bahwa sistem informasi adalah suatu sistem di dalam suatu organisasi yang mempertemukan kebutuhan pengolahan transaksi harian yang mendukung fungsi operasi organisasi yang bersifat manajerial dengan kegiatan strategi dari suatu organisasi untuk dapat menyediakan kepada pihak luar tertentu dengan laporan-laporan yang diperlukan.

Sedangkan menurut Kusrini (2007:11) sistem informasi adalah suatu sistem di dalam suatu organisasi yang mempertemukan kebutuhan pengolahan transaksi harian, mendukung operasi, bersifat manajerial dan merupakan kegiatan strategi dari suatu organisasi, serta menyediakan laporan-laporan yang diperlukan oleh pihak luar.

\section{Konstruksi Jalan}

Menurut peraturan pemerintah RI, No. 34 Tahun 2006, menjelaskan bahwa konstruksi jalan baru merupakan penanganan jalan dari kondisi belum tersedia badan jalan sampai kondisi jalan dapat berfungsi.

Sedangkan menurut Hafizah (2011), konstruksi jalan merupakan jalurjalur diatas permukaan bumi yang sengaja 
Available online at http://jurnal.stmikroyal.ac.id/index.php/jurteksi

dibuat oleh manusia dengan ukuran, konstruksi dan bentuk tertentu sehingga dapat dipakai sebagai jalur lalu lintas orang, hewan dan kendaraan.

Dari kedua pendapat di atas dapat disimpulkan bahwa konstruksi jalan merupakan proses pembuatan jalan yang dikerjakan oleh manusia mulai dari tahap perencanaan pembuatan sampai jalan tersebut sudah selesai dibuat dan berfungsi bagi pengguna jalan tersebut.

\section{Metode Waterfall}

Metode air terjun atau yang sering disebut metode waterfall sering dinamakan siklus hidup klasik (classic life cycle), dimana hal ini menggambarkan pendekatan yang sistematis dan juga berurutan pada pengembangan perangkat lunak, dimulai dengan spesifikasi kebutuhan pengguna lalu berlanjut melalui tahapan-tahapan perencanaan (planning), permodelan (modeling), konstruksi (construction), serta penyerahan sistem ke para pelanggan/ pengguna (deployment), yang diakhiri dengan dukungan pada perangkat lunak lengkap yang dihasilkan (Pressman, 2012). Tahapan metode waterfall dapat dilihat pada gambar di bawah ini.

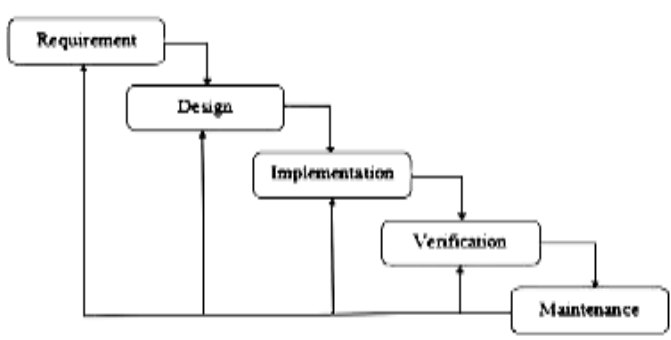

Gambar 1. Konseptual Metode Waterfall

Dalam pengembangannya metode waterfall memiliki beberapa tahapan yang berurut yaitu: requirement (analisis kebutuhan), design system (desain sistem), Coding (pengkodean) dan Testing (pengujian), Penerapan Program, pemeliharaan. Tahapan tahapan dari metode waterfall adalah: (1) Requirement Analisis, Tahap ini pengembang sistem diperlukan komunikasi yang bertujuan untuk memahami perangkat lunak yang diharapkan oleh pengguna dan batasan perangkat lunak tersebut. Informasi ini biasanya dapat diperoleh melalui wawancara, diskusi atau survei langsung. Informasi dianalisis untuk mendapatkan data yang dibutuhkan oleh pengguna, (2) System Design, Spesifikasi kebutuhan dari tahap sebelumnya akan dipelajari dalam fase ini dan desain sistem disiapkan. Desain Sistem membantu dalam menentukan perangkat keras (hardware) dan sistem persyaratan dan juga membantu dalam mendefinisikan arsitektur sistem secara keseluruhan, (3) Implementation, Pada tahap ini, sistem pertama kali dikembangkan di program kecil yang disebut unit, yang terintegrasi dalam tahap selanjutnya. Setiap unit dikembangkan dan diuji untuk fungsionalitas yang disebut sebagai unit testing, (4) Integration \& Testing. Seluruh unit yang dikembangkan dalam tahap implementasi diintegrasikan ke dalam sistem setelah pengujian yang dilakukan masing-masing unit. Setelah integrasi seluruh sistem diuji untuk mengecek setiap kegagalan maupun kesalahan, (5) Operation \& Maintenance, Tahap akhir dalam model waterfall. Perangkat lunak yang sudah jadi, dijalankan serta dilakukan pemeliharaan. Pemeliharaan termasuk dalam memperbaiki kesalahan yang tidak ditemukan pada langkah sebelumnya. Perbaikan implementasi unit sistem dan peningkatan jasa sistem sebagai kebutuhan baru.

\section{METODOLOGI}

Metodologi penelitian adalah gambaran dari langkah-langkah yang dilakukan dalam melakukan penelitian. Ini perlu ditetapkan agar penelitian dapat dilakukan dengan terstruktur atau mempermudah menyelesaikan permasalah yang terjadi pada penelitian yang dilakukan. Langkah yang dilakukan harus 
Available online at http://jurnal.stmikroyal.ac.id/index.php/jurteksi

mencakup mulai dari mempelajari masalah sampai dengan adanya suatu sistem yang dapat dihasilkan sehingga masalah dapat teratasi.

Adapun kerangka kerja dari penelitian ini dapat di lihat pada gambar kerangka kerja penelitian di bawah ini:

1. Analisa Kebutuhan

Analisa kebutuhan berdasarkan obeservasi terlebih dahulu terhadap objek penelitian dan mengidentifikasi masalah pada objek penelitian tersebut. Berdasarkan pengamatan yang peneliti lakukan pada PT. Barettamuda Pratama Padang, ditemukan beberapa permasalahan mendasar terkait pada data pelaksanaan kosntruksi pembangunan jalan yaitu, sering terlambat penyampaian informasi/laporan pada pimpinan, kesalahan dalam penulisan data, kesulitan ketika mencari data yang dibutuhkan, dan terjadi redudansi data pada informasi/laporan. Kelemahan yang terjadi pada sistem yang digunakan mengakibatkan ketidakefektifan dalam mengerjakan laporan dan waktu yang digunakan tidak efesien.

2. Desain Sistem

Pada tahap pengembangan dan perancangan akan diuraikan dalam bentuk Context Diagram, Data Flow Diagram (DFD), Entity Relationship Diagram(ERD), rancangan output, rancangan proses, dan rancangan input. Adapun tools yang digunakan dalam pembuatan sistem adalah Visual Basic 6.0 dan media penyimpanan data menggunakan Xampp.

3. Penulisan Kode Program

Setelah tahap desain sistem dilanjutkan dengan menulis kode program yang tujuannya adalah agar sistem dapat berfungsi sebagaimana yang diharapkan. Penulisan kode program ini meliputi input data, proses data, dan output data pelaksanaan konstruksi jalan.

4. Pengujian Sistem
Sebelum program diterapkan, program harus bebas terlebih dahulu darikesalahan-kesalahan yang mungkin terjadi. Program diuji tiap-tiap modul dan dilanjutkan dengan pengujian ke semua modul yang telah dirangkai. Kesalahan yang mungkin terjadi dapat diklasifikasikan dalam tiga bentuk, yaitu sebagai berikut:

a. Kesalahan bahasa (Language errors) atau disebut juga dengan kesalahan penulisan (Syntax error), adalah kesalahan dalam menulis penulisan source program yang tidak sesuai dengan yang sudah diisyaratkan.

b. Kesalahan waktu proses (Runtime errors), adalah kesalahan yang terjadi sewaktu program dijalankan. Kesalahan ini akan menyebabkan proses program terhenti sebelum selesai pada saatnya karena compiler menemukan kondisikondisi yang belum terpenuhi yang tidak terbiasa dikerjakan.

c. Kesalahan logika (Logical errors), adalah kesalahan dari logika program yang dibuat.

Setelah bebas dari kesalahan, dilanjutkan dengan pengujian sistem. Tujuan utama dari pengujian sistem adalah untuk memastikan bahwa elemen-elemen atau komponenkomponen dari sistem telah berfungsi sesuai dengan yang diharapkan.

5. Penerapan Program dan Pemeliharaan Tahap ini merupakan tahap terakhir dalam menggambarkan sistem, yaitu meletakan sistem supaya siap dioperasikan. Implementasi berguna untuk memudahkan penerapan sistem yang disiapkan agar pengentrian data sampai pada penyajian informasi sesuai dengan prosedur yang telah direncanakan. Data yang digunakan adalah data pelaksanaan konstruksi pembangunan jalan. Setelah sistem diterapkan dan digunakan sebagaimana mestinya, dilakukan pemeliharaan sistem agar sistem dapat 
Available online at http://jurnal.stmikroyal.ac.id/index.php/jurteksi

digunakan dengan jangka waktu panjang. Pemeliharaan juga bertujuan untuk tahap pengembangan selanjutkan dengan cara melakukan evaluasi sistem.

\section{HASIL DAN PEMBAHASAN}

\section{Menu Utama}

Menu utama merupakan kerangka dasar dari beberapa sub program yang ada didalamnya sebagai tampilan utama dari program sistem informasi pengolahan data pelaksanaan konstruksi pembangunan jalan pada PT. Barettamuda Pratama Padang.

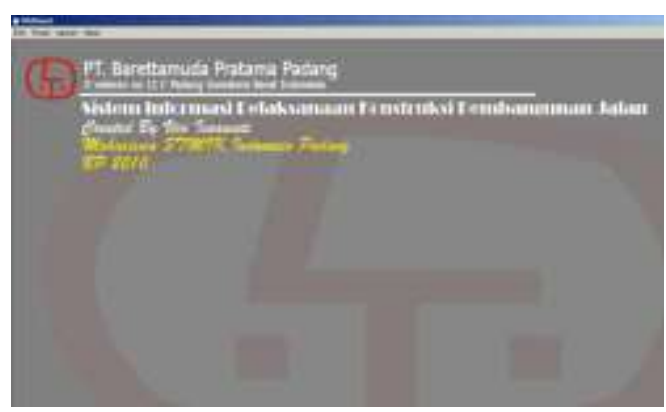

Gambar 2. Menu Utama Sistem Informasi Pengolahan Data Pelaksanaan Konstruksi Pembangunan Jalan

\section{Input Data Bahan Konstruksi}

Form ini merupakan form untuk mengentrikan data Bahan Konstruksi. Dalam form ini dirancang beberapa tombol yaitu tambah, simpan, koreksi, hapus, dan keluar. Tombol tambah dan tombol simpan berfungsi menambah dan menyimpan data Bahan Konstruksi yang dientrikan. Tombol koreksi berfungsi memperbaiki data yang salah. Tombol hapus berfungsi menghapus data yang ada. Tombol keluar berfungsi sebagai perintah keluar dari form.

1. Input Data Lokasi Pembangunan Jalan Form ini merupakan form untuk mengentrikan data Lokasi Pembangunan Jalan. Dalam form ini dirancang beberapa tombol yaitu tambah, simpan, koreksi, hapus, dan keluar. Tombol tambah dan tombol simpan berfungsi menambah dan menyimpan data Lokasi Pembangunan Jalan yang dientrikan. Tombol koreksi berfungsi memperbaiki data yang salah. Tombol hapus berfungsi menghapus data yang ada. Tombol keluar berfungsi sebagai perintah keluar dari form.

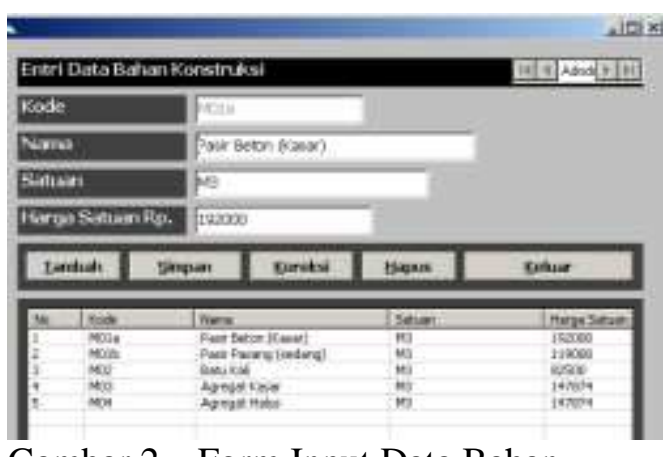

Gambar 2. Form Input Data Bahan Konstruksi

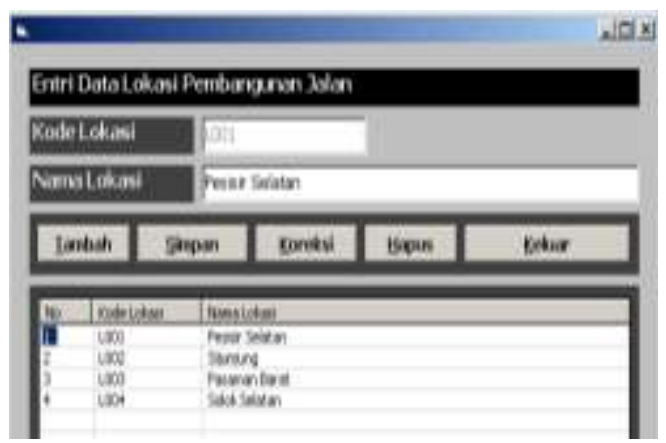

Gambar 3. Form Input Data Lokasi Pembangunan Jalan

\section{Input Data Perusahaan}

Form ini merupakan form untuk mengentrikan data Perusahaan. Dalam form ini dirancang beberapa tombol yaitu tambah, simpan, koreksi, hapus, dan keluar. Tombol tambah dan tombol simpan berfungsi menambah dan menyimpan data Perusahaan yang dientrikan. Tombol koreksi berfungsi memperbaiki data yang salah. Tombol hapus berfungsi menghapus data yang ada. Tombol keluar berfungsi sebagai perintah keluar dari form. 
Available online at http://jurnal.stmikroyal.ac.id/index.php/jurteksi

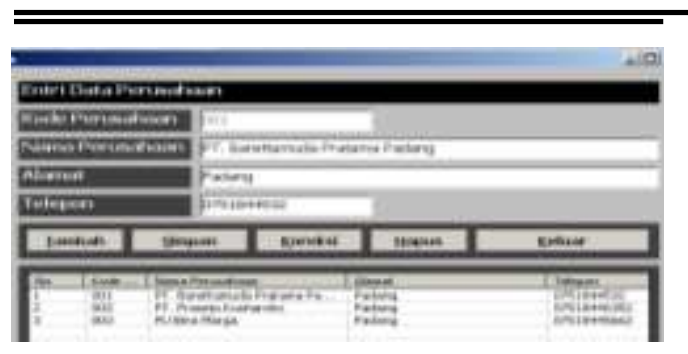

Gambar 4. Form Input Data Perusahaan

Form proses merupakan form yang memproses data Kontrak Pembangunan Jalan. Dalam form ini dirancang beberapa tombol yaitu tambah, simpan, koreksi, hapus, dan keluar. Tombol tambah dan tombol simpan berfungsi menambah dan menyimpan data Kontrak Pembangunan Jalan yang dientrikan. Tombol koreksi berfungsi memperbaiki data yang salah. Tombol hapus berfungsi menghapus data yang ada. Tombol keluar berfungsi sebagai perintah keluar dari form.

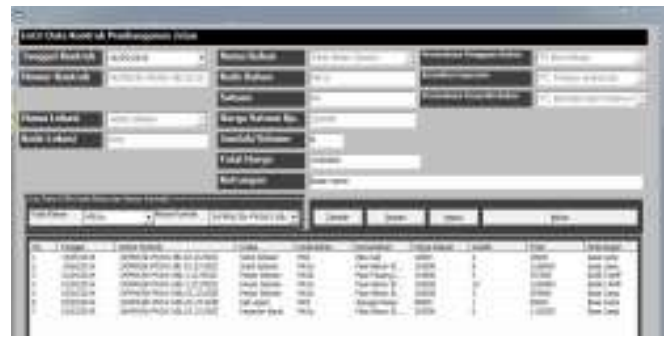

Gambar 5. Form Proses Data Kontrak Pembangunan Jalan

3. Laporan Rincian Pembayaran

Sebelum laporan dimunculkan, maka akan tampil form penghubung laporan, seperti pada Gambar 6.

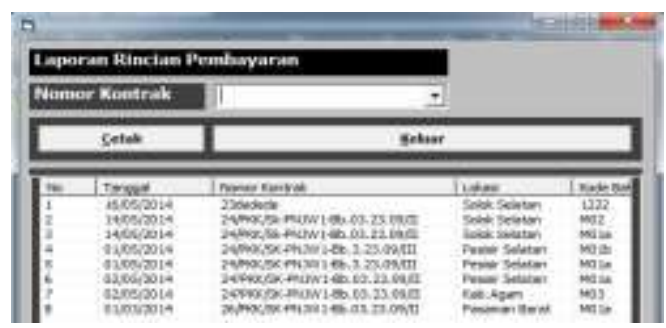

Gambar 6. Form Penghubung Laporan Rincian Pembayaran
Pada form penghubung Laporan Rincian Pembayaran tersedia dua buah Command Button, yaitu cetak dan keluar. Jika di klik cetak, maka akan ditampilkan pada monitor Laporan Rincian Pembayaran dan jika di klik keluar, maka form penghubung akan ditutup dan kembali ke menu utama.

Adapun bentuk Laporan Rincian Pembayaran pada sistem informasi pengolahan data pelaksanaan konstruksi pembangunan jalan Pada PT. Barettamuda Pratama Padang dapat dilihat pada Gambar 7.

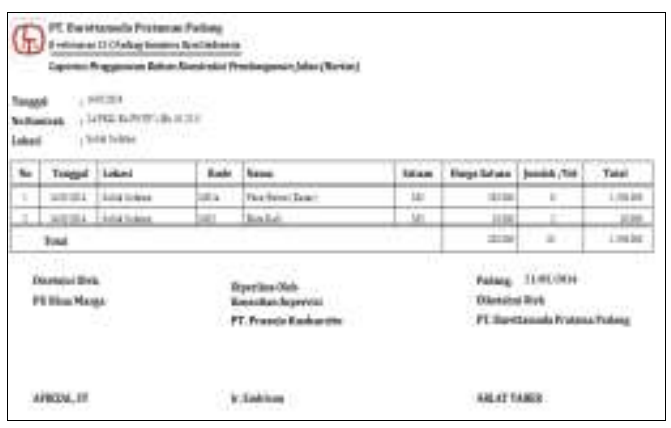

Gambar 7. Laporan Rincian Pembayaran

4. Laporan Penggunaan Bahan Konstruksi Pembangunan Jalan (Harian)

Sebelum laporan dimunculkan, maka akan tampil form penghubung laporan, seperti pada Gambar 8.

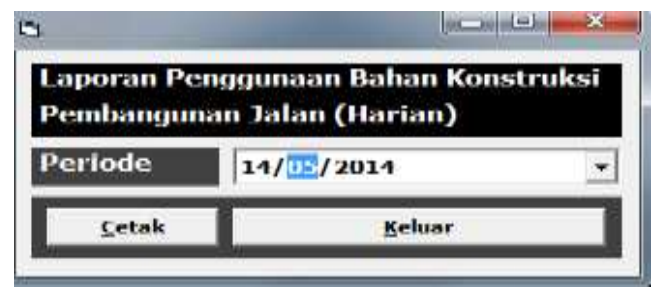

Gambar 8. Form Penghubung Laporan Penggunaan Bahan Konstruksi Pembangunan Jalan (Harian)

Pada form penghubung Laporan Penggunaan Bahan Konstruksi Pembangunan Jalan (Harian) tersedia dua buah Command Button, yaitu cetak dan keluar. Jika di klik cetak, maka akan 
Available online at http://jurnal.stmikroyal.ac.id/index.php/jurteksi

ditampilkan pada monitor Laporan Penggunaan Bahan Konstruksi Pembangunan Jalan (Harian) dan jika di klik keluar, maka form penghubung akan ditutup dan kembali ke menu utama.

Adapun bentuk Laporan Penggunaan Bahan Konstruksi Pembangunan Jalan (Harian) pada sistem informasi pengolahan data pelaksanaan konstruksi pembangunan jalan Pada PT. Barettamuda Pratama Padang pada gambar 9.

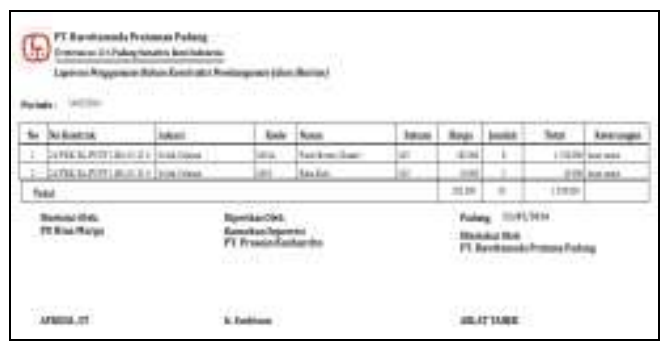

Gambar 10. Laporan Penggunaan Bahan Konstruksi Pembangunan Jalan (Harian)

5. Laporan Penggunaan Bahan Konstruksi Pembangunan Jalan (Bulanan)

Sebelum laporan dimunculkan, maka akan tampil form penghubung laporan, seperti pada Gambar 11.

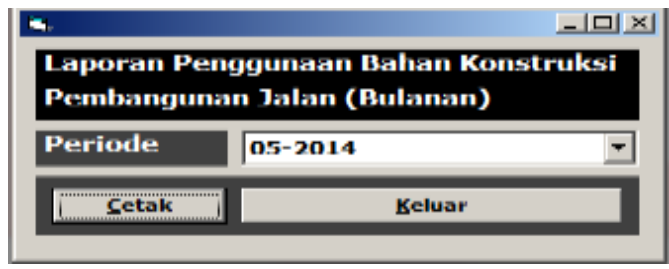

Gambar 11. Form Penghubung Laporan Penggunaan Bahan Konstruksi Pembangunan Jalan (Bulanan)

Pada form penghubung Laporan Penggunaan Bahan Konstruksi Pembangunan Jalan (bulanan) tersedia dua buah Command Button, yaitu cetak dan keluar. Jika di klik cetak, maka akan ditampilkan pada monitor Laporan Penggunaan Bahan Konstruksi Pembangunan Jalan (bulanan) dan jika di klik keluar, maka form penghubung akan ditutup dan kembali ke menu utama.

Adapun bentuk Laporan Penggunaan Bahan Konstruksi Pem-bangunan Jalan (bulanan) pada sistem informasi pengolahan data pelaksanaan konstruksi pembangunan jalan Pada PT. Barettamuda Pratama Padang pada gambar 12.

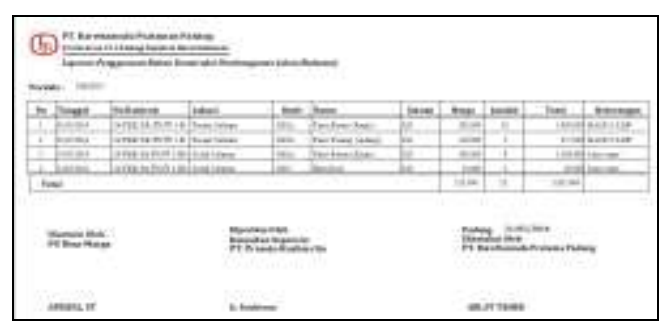

Gambar 12. Laporan Penggunaan Bahan Konstruksi Pembangunan Jalan (Bulanan)

6. Laporan Penggunaan Bahan Konstruksi Pembangunan Jalan (tahunan)

Sebelum laporan dimunculkan, maka akan tampil form penghubung laporan, seperti yang terlihat pada gambar 13.

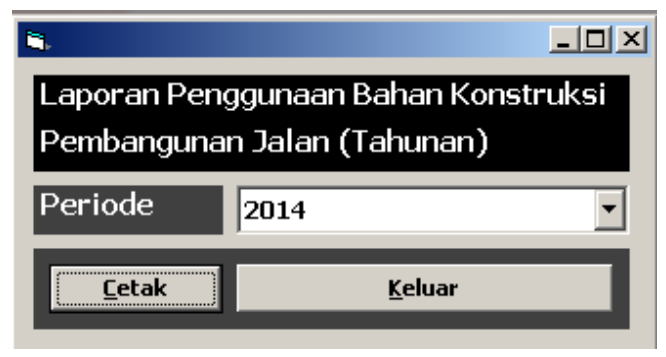

Gambar 13. FormPenghubung Laporan Penggunaan Bahan Konstruksi Pembangunan Jalan (Tahunan)

Pada form penghubung Laporan Penggunaan Bahan Konstruksi Pembangunan Jalan (tahunan) tersedia dua buah Command Button, yaitu cetak dan keluar. Jika di klik cetak, maka akan ditampilkan pada monitor Laporan Penggunaan Bahan Konstruksi Pembangunan Jalan (tahunan) dan jika di klik keluar, maka form penghubung akan ditutup dan kembali ke menu utama. 
Available online at http://jurnal.stmikroyal.ac.id/index.php/jurteksi

Adapun bentuk Laporan Penggunaan Bahan Konstruksi Pem-bangunan Jalan (tahunan) pada informasi pengolahan data pelaksanaan konstruksi pembangunan jalan Pada PT. Barettamuda Pratama Padang pada gambar 14.

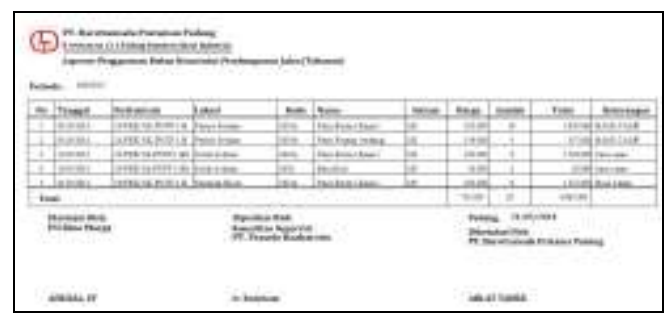

Gambar 14. Laporan Penggunaan Bahan Konstruksi Pembangunan Jalan (Tahunan)

\section{SIMPULAN}

Berdasarkan pembahasan yang telah dilakukan, maka peneliti dapat mengambil simpulan sebagai berikut:
1. Sistem informasi pengolahan data pelaksanaan konstruksi pembangunan jalanberguna membantu kinerja PT. Barretamuda Pratama Padang dalam hal pengolahan data pelaksanaan konstruksi pembangun-an jalan.

2. Pembangunan sistem lama pada sistem baru pada sistem pengolahan data pelaksanaan konstruksi pembangunan jalan menerapkan metode Waterfall. Kelebihan metode waterfall, praktis dalam merekaya sistem, Pengembangan yang terstruktur dan terkontrol membuat kualitas software tetap terjaga. Disisi lain model ini merupakan jenis model yang bersifat dokumen lengkap, sehingga proses pemeliharaan dapatdilakukan dengan mudah.

3. Sistem informasi ini memudahkan dalam proses pengecekan atau pencarian data yang dibutuhkan dan mencegah redudansi data, sehingga informasi yang disajikan akurat dan dapat dipercaya.

\section{DAFTAR PUSTAKA}

Atmoko, E.K. (2013). Point Of Sales dengan Proteksi Setoran Kasir dan Stock Menggunakan VB 6. Jakarta: Elex Media Komputindo

Kusrini. (2007). Konsep dan Aplikasi Sistem Pendukung Keputusan. Yogyakarta: Andi Offset
Pangestu. W.D. (2007). Teori Dasar Sistem Informasi Manajemen. http://ilmukomputer.org/wpcontent/uploads/2008/08/sim. $p d f$.

Subari, T. (2012). Konsep Sistem Informasi. Yogyakarta: Andi Offset 
Available online at http://jurnal.stmikroyal.ac.id/index.php/jurteksi 
Jurnal Pena Edukasi

ISSN 2407-0769

Vol. 4 No. 2, Maret 2017

e-ISSN 2549-4694 